\section{Micropropagation of Two Selected Male Kiwifruit and Analysis of Genetic Variation with AFLP Markers}

\author{
M.J. Prado ${ }^{1}$ and M.T. Herrera \\ Dpto. Fisiología Vegetal, Escuela Politécnica Superior, Universidad de Santiago \\ de Compostela, Campus de Lugo, 27002 Lugo, Spain
}

R.A. Vázquez

Dpto. Botánica, Escuela Politécnica Superior, Universidad de Santiago de Compostela, Campus de Lugo, 27002 Lugo, Spain

\section{S. Romo and M.V. González}

Dpto. Fisiología Vegetal, Escuela Politécnica Superior, Universidad de Santiago de Compostela, Campus de Lugo, 27002 Lugo, Spain

Aditional index words. Actinidia deliciosa, tissue culture, shoot tips, BA, thidiazuron, metatopolin, somaclonal variation, AFLPs

Abstract. A simple and reliable protocol for micropropagation during 12 subcultures of two field growth male plants of kiwifruit [Actinidia deliciosa (A.Chev.) Liang and Ferguson] is described. The best results of shoot multiplication and elongation were obtained in Cheng's K(h) medium in the presence of $0.5 \mu \mathrm{M}$ NAA, $22 \mu \mathrm{M}$ BA and $1.4 \mu \mathrm{M} \mathrm{GA}$ for 'Tomuri' explants, and of $0.1 \mu \mathrm{M}$ NAA, $4.4 \mu \mathrm{M}$ BA, and $0.3 \mu \mathrm{M}$ GA for clone A explants. In addition, the cytokinin compounds TDZ and $\mathrm{mT}$ were also tested allowing improving the multiplication rate in 'Tomuri' explants. For rooting, 'Tomuri' and clone A developed shoots were treated by basal immersion in a 5 mM IBA solution for 15 seconds. Treated shoots were then cultured in half-strength $K(h)$ medium without growth regulators showing $100 \%$ rooting after 30 days. Regenerated plantlets were successfully transplanted to soil $(90 \%$ survival) and they are actively growing in the field. Somaclonal variation analysis by AFLP was carried out using 15 primer combinations, yielding reproducible and wellresolved bands with a $57 \%$ of polymorphism. AFLP markers showed to be effective to discriminate genetic variation in this species, being greater in clone $A$ than 'Tomuri'. Chemical names used: $\mathbf{N}^{6}$-benzyladenine (BA); gibberellic acid (GA G $_{3}$; indole-3-butyric acid (IBA); meta-topolin (mT); naphthaleneacetic acid (NAA); thidiazuron (TDZ).

Kiwifruit[Actinidiadeliciosa(Chev.)Liang and Ferguson] is a domesticated plant, and their fruits are mostly produced by one female cultivar ('Hayward'). Pollination is one of the main factors limiting kiwifruit production, since inadequate pollination leads to small unmarketable fruits (González et al., 1998). Pollination mostly relies on two male clones 'Matua' and 'Tomuri' selected in New Zealand (Zhang and Thorp, 1986), but in several European countries these males produce little pollen and the flowering period does not exactly coincide with the female cultivar 'Hayward'.

Received for publication 14 Jan. 2004. Accepted for publication 28 Sept. 2004. We would like to acknowledge to Ministerio de Educación y Cultura (Project CICYT 1FD97-1208) for their financial support, and the Xunta de Galicia for the award of a fellowship to M.J.Prado. We sincerely thank Raffaelle Testolin for his collaboration in the area of genetic analysis, and Manuel Rey for his assistance in making bibliographical revisions. We would also like to thank SERIDA-Consejeria de Medio Rural y Pesca del Principado de Asturias (Spain)-for providing the male plants. We thank anonymous reviewers for their critical comments.

${ }^{1}$ Current address: Dpto. Fisiología Vegetal, Escuela Politécnica Superior, Universidad de Santiago de Compostela, Campus de Lugo, 27002, Lugo, Spain. To whom reprint requests should be addressed; emailmjprado@yahoo.es.
This situation has led to the use of nonselected male plants in commercial orchards, and the search for other good male pollinizer clones for 'Hayward', such as selected clone A in Spain (González et al., 1994).

Selected pollinizers would allow commercial orchards to replace those male plants with less flowers and pollen and which do not flower at the same time as 'Hayward' with selected male kiwifruit plants. This situation creates the need for a great number of male plants from a single mother plant, which could be obtained by in vitro culture. This technique will be especially useful given that several wood-transmitted diseases have recently been detected in kiwifruit (Di Marco et al., 2002; Gianetti et al., 2002), which makes traditional propagation protocols, such as grafting, more difficult. Several protocols for micropropagation have been published for the female cultivar 'Hayward' using shoot or root segments, buds, meristem tips or other explants (Revilla et al., 1992). While the main methods used for clonal micropropagation were carried out with nodal segments (Piagnani et al., 1986; Velayandom et al., 1985), shoot tips (Monette, 1986) or axillary buds (Pedroso et al., 1992; Wessels et al., 1984), few studies have reported clonal micropropagation from male cultivars such as 'Tomuri'(Marino and Bertazza, 1990; Piagnani et al., 1986). Most of these reports used $\mathrm{N}^{6}$ benzyladenine (BA) as the cytokinin, and only a few of them also tested the effect of zeatin (Z) and kinetin (KIN). Recent studies have introduced other cytokinins such as thidiazuron (TDZ), which has not been previously assayed in Actinidia, or meta-topolin (mT) that it has been shown that doubles the multiplication rate in this species (Fernández, 2001).

In plant propagation, the most crucial concern is to retain genetic integrity with respect to the parent plants. However, it has been reported that in vitro culture techniques induce genetic, specifically somaclonal, variation (Larkin and Scowcroft, 1981). The variability expressed in microplants may be the consequence of, or related to, oxidative stress damage caused to the plant tissues during explant preparation, and in culture as a result of media and environmental factors (Cassells and Curry, 2001). Phenotypic identification has been one of the strategies used to detect genetic variation, although some changes induced by in vitro culture cannot be observed because the structural difference in the gene product does not always alter its biological activity sufficiently for the change to be detectable in the phenotype (Palombi and Damiano, 2002). Consequently, DNA analysis techniques are also used. Some of these techniques assess somaclonal variation, such as RFLP and isozymes (Sabir et al., 1992), RAPD markers (Hashmi et al., 1997; Schneider et al., 1996) and AFLP markers (Vendrame et al., 1999). In kiwifruit, studies of somaclonal variation in 'Tomuri', M3, CI.Gi and 'Hayward' microcultures have recently been established, starting from shoot meristems and through the adventitious regeneration of fruit peduncles, using RAPD and SSR (Palombi and Damiano, 2002).

In our report, we describe a complete and reliable system for male kiwifruit plant micropropagation from shoot-tips of hardwood from field-grown plants and the analysis of genetic variation induced by in vitro culture carried out using AFLP markers.

\section{Materials and Methods}

Plant material. Hardwood cuttings from adult plants of cultivar Tomuri (Zhang and Thorp, 1986) and clone A (González et al., 1994), both male kiwifruit plants (Actinidia deliciosa), were used as explant sources. These cuttings, collected in January 2000 and 2001 at experimental orchards located in the SERIDA (Villaviciosa, Principado de Asturias, Spain), were subjected to two different methods of sterilization and storage. Protocol A: cuttings were directly stored inside a plastic bag at $4^{\circ} \mathrm{C}$ for at least 2 months and surface sterilized with sodium azide $0.4 \%$ just before stimulating budbreak. Protocol B: cuttings were surface sterilized as for protocol A and then stored at $4{ }^{\circ} \mathrm{C}$ for at least 2 months before stimulating budbreak. In both protocols, cuttings were stimulated to budbreak by placing them in water in a growth chamber at $24 \pm 2{ }^{\circ} \mathrm{C}$ with a 16 -h photoperiod (cool white light fluorescent tubes, $\left.60 \mu \mathrm{mol} \cdot \mathrm{m}^{-2} \cdot \mathrm{s}^{-1}\right)$. Lateral shoots produced after budbreak were then used as explant sources. 
Fungal analysis. Sanitary state of plants was controlled periodically during the micropropagation process. All stock cuttings and micropropagated shoots with symptoms were analysed for fungal diseases. Samples were transferred to 90 -mm-diameter petri plates containing malt extract agar ( $10 \mathrm{~g}$ malt extract, Cultimed; $10 \mathrm{~g}$ agar, general purpose agar, Sigma; 1L distilled water). Plates were incubated at 20 to $22{ }^{\circ} \mathrm{C}$ with a $16 \mathrm{~h}$ dark $-8 \mathrm{~h}$ light cycle (cool-white light fluorescent tubes, $\left.80 \mu \mathrm{mol} \cdot \mathrm{m}^{-2} \cdot \mathrm{s}^{-1}\right)$. Fungi were examined $\mathrm{mi}-$ croscopically (Olympus $\mathrm{CH}-2$ ) and identified using diagnostic morphological criteria found in Barnett and Hunter (1987), Ellis (1971) and Sutton (1980).

Tissue culture. Shoot tips were used as primary explants. They were sterilized by immersion in $70 \%$ ethanol for $20 \mathrm{~s}$ and then in $1 \%$ sodium hypochlorite with three drops of Tween- 20 for $20 \mathrm{~min}$. Finally they were washed three times with sterile distilled water.

Shoot tips were cultured in baby food-jars covered with MAGENTA caps (Sigma) containing $30 \mathrm{~mL}$ of basal $\mathrm{K}(\mathrm{h})$ medium (Cheng, 1975) either without or supplemented with four different growth regulator combinations. The combinations tested were $0.1 \mu \mathrm{M}$ 1-naphthaleneacetic acid (NAA), $0.4 \mu \mathrm{M}$ BA and $0.3 \mu \mathrm{M}$ gibberellic acid (GA $)(\mathrm{M} 1) ; 0.1$ $\mu \mathrm{M}$ NAA, $4.4 \mu \mathrm{M}$ BA and $0.3 \mu \mathrm{M} \mathrm{GA}_{3}(\mathrm{M} 2)$; $0.5 \mu \mathrm{M}$ NAA, $2.2 \mu \mathrm{M}$ BA and $1.4 \mu \mathrm{M} \mathrm{GA}_{3}$ (M3); $0.5 \mu \mathrm{M}$ NAA, $22 \mu \mathrm{M}$ BA and $1.4 \mu \mathrm{M}$ $\mathrm{GA}_{3}$ (M4). Explants were transferred to the same fresh medium monthly and the number of new shoots per explant was counted. The effect of TDZ and $\mathrm{mT}$ was assayed by culturing 'Tomuri' shoot tips with $0.5 \mu \mathrm{M}$ NAA, $2.2 \mu \mathrm{M}$ TDZ and $1.4 \mu \mathrm{M} \mathrm{GA}_{3}$ or $0.5 \mu \mathrm{M}$ NAA, $2 \mu \mathrm{M}$ $\mathrm{mT}$ and $1.4 \mu \mathrm{M} \mathrm{GA}_{3}$, and clone A shoot tips in $0.1 \mu \mathrm{M}$ NAA, $0.4 \mu \mathrm{M}$ TDZ and $0.3 \mu \mathrm{M} \mathrm{GA}_{3}$, or $0.1 \mu \mathrm{M}$ NAA, $2 \mu \mathrm{M} \mathrm{mT}$, and $0.3 \mu \mathrm{M} \mathrm{GA}_{3}$. The explants from 'Tomuri' were then transferred and maintained during several subcultures in M4 medium and those from clone A in M2 medium, and transferred to the same fresh medium on a monthly basis.

Rooting induction was carried out by immersion of the basal part of shoots from M1, M2 and M4 multiplication medium into a solution of indole-3-butyric acid (IBA) ( $5 \mathrm{mM}$ ) for $15 \mathrm{~s}$, followed by culturing in a half-strength $\mathrm{K}(\mathrm{h})$ basal medium. Regenerated plantlets were transferred to a sterile 1 peat : 1 perlite (by volume) substrate in baby-food jars for $10 \mathrm{~d}$, with a gradual opening of the cover. After this procedure, they were transferred to soil (1 peat $: 1$ perlite, by volume) under a mist chamber in a greenhouse (González et al., 1995).

All media contained 3\% sucrose and the $\mathrm{pH}$ was adjusted to 5.7 to 5.8 before autoclaving. They were all solidified with $1 \%$ agar (General purpose agar, Sigma) and autoclaved for $20 \mathrm{~min}$ at $120^{\circ} \mathrm{C}$ and $98 \mathrm{KPa}$. Cultures were incubated in a growth chamber at $25 \pm 2{ }^{\circ} \mathrm{C}$ with a $16 \mathrm{~h}$ photoperiod (GROLUX white light fluorescent tubes, $\left.110 \mu \mathrm{mol} \cdot \mathrm{m}^{-2} \cdot \mathrm{s}^{-1}\right)$.

Genetic variation analysis. Both in vivoand in vitro-grown kiwifruit male genotypes ('Tomuri' and clone A) were used for AFLP analysis. In vitro material consisted of prolifer- ated shoots collected during two periods: first from the most reactive subculture, and second from the last subculture in the best medium for each genotype. In vivo material were young developing leaves from field grown plants of same genotypes.

Total DNA was extracted from $1 \mathrm{~g}$ fresh weight of young leaves with CTAB buffer and the procedure described by Doyle and Doyle (1990), as modified slightly by Cipriani and Morgante (1993). The DNA suspension was purified of polysaccharides with 2-butoxyethanol according to the procedure described by Manning (1991). For analysing somaclonal variation induced by the in vitro culture, AFLP markers were produced using the 15 primer combinations selected by Testolin et al. (2001). DNA digestion, adaptor ligation and pre-and selective amplifications were carried out according to manufacturers' instructions (GIBCOBRL,Life Technologies) and standard procedures (Vos et al., 1995). Selective amplification was carried out using $\left[{ }^{33} \mathrm{P}\right]$-labelled EcoRI primer with the following temperature profile: 12 cycles of $94{ }^{\circ} \mathrm{C}$ for $30 \mathrm{~s}, 65^{\circ} \mathrm{C}$ for $30 \mathrm{~s}, 72{ }^{\circ} \mathrm{C}$ for each cycle (touch-down); 23 cycles of $94{ }^{\circ} \mathrm{C}$ for $30 \mathrm{~s}, 56{ }^{\circ} \mathrm{C}$ for $30 \mathrm{~s}, 72^{\circ} \mathrm{C}$ for $60 \mathrm{~s}$. PCR reactions were mixed with $2.5 \mu \mathrm{L}$ formamide dye, heated at $95^{\circ} \mathrm{C}$ for $5 \mathrm{~min}$ and then quickly cooled on ice. Three microliters from each sample were loaded on a $6 \%$ denaturing polyacrylamide gel(Bio-Rad Laboratories S.A.) containing $7 \mathrm{M}$ urea and run at $58 \mathrm{~W}$ for $2 \mathrm{~h}$. After electrophoresis, the gel was dried on Watmann 3MM paper in a vacuum dryer at 80 ${ }^{\circ} \mathrm{C}$ for $2 \mathrm{~h}$ and autoradiographed on X-ray film (Kodak) using standard procedures.

Data analysis. All tissue culture experiments were performed at least three times with a minimum of 10 explants per treatment and repetition. Data was statistically analysed using one-way analysis of variance (ANOVA) and the differences contrasted using Duncan's multiple range test $(P \leq 0.05)$.

AFLP reproducible fragments were scored as present (1) or absent (0), and bands were entered in a computer file as a binary matrix.

Table 1. Fungi isolated after sterilization of cuttings following protocols ${ }^{\mathrm{Z}} \mathrm{A}$ or $\mathrm{B}$.

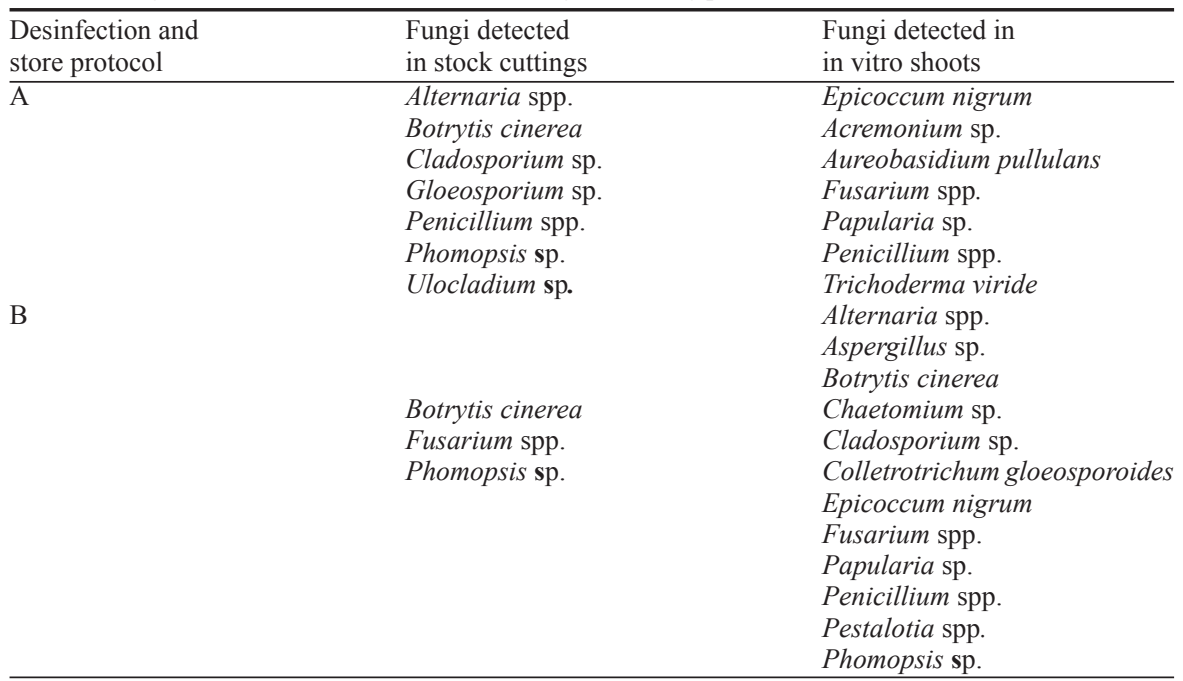

${ }^{2}$ Protocol A: cuttings were directly stored in a plastic bag at $4{ }^{\circ} \mathrm{C}$ for at least 2 months and then surface sterilized with sodium azide $0.4 \%$ just before stimulating budbreak. Protocol B: cuttings were surface sterilized as for protocol $\mathrm{A}$ and stored at $4{ }^{\circ} \mathrm{C}$ for at least 2 months before stimulating budbreak.
The matrix was then analysed by the program Numerical Taxonomy System(NTSYS v.2.10). Similarities in data were computed using the Dice similarity index, and similarity estimated was analysed by the UPGMA (Unweighted Pair-Group Method Arithmetic averages); resulting cluster was expressed in a dendrogram. Data was analysed in a binary matrix containing all of the fragments obtained, both monomorphic and polymorphic bands. From the data set obtained, we calculated a cophenetic correlation coefficient using Mantel test (Mantel, 1967) to evaluate how well the dendrogram represented the relationships among genotypes.

\section{Results and Discussion}

Effect of stock cuttings protocols. Fungi isolated after sterilization following protocolA or $\mathrm{B}$ differed markedly in species composition (Table 1). Pathogenic fungi such as Botrytis cinerea and Phomopsis were isolated from both clone A and 'Tomuri' stock cuttings. In protocol $\mathrm{B}$ cuttings, $B$. cinerea was the dominant species with other possible pathogens (especially Phomopsis). On the other hand, a greater diversity was observed in fungi isolated from the protocol A cuttings.

Previous disinfection of stock cuttings (protocol B) removed a lot of fungi inhabiting the surface of plant material (phylloplane) and only those fungi with the ability to develop resistant forms (like sclerotia) were able to be stored without antagonist competition and subsequent prevalent contamination.

The inhibition of pathogens like Botrytis cinerea by antagonists from phylloplane has been reported (Cook and Baker, 1983). Antagonistic fungi like Ulocladium atrum have been selected for their ability to control $B$. cinerea in several crops including stock cuttings (Gerlach et al., 2001; Köhl et al., 1998; Thanassoulopoulos and Yanna, 1997). Table 1 shows Ulocladium sp. presence in cuttings sterilized following protocol B. It is possible that Ulocladium $\mathrm{sp}$. protocol $\mathrm{A}$ and their absence in those from 
was effective in controlling the pathogens in the cuttings sterilized just before budbreak. Using protocol B, Ulocladium sp. was suppressed because of sterilization and $B$. cinerea populations subsequently increased. This problem affected the survival of shoots-tips in culture, so that 'Tomuri' shoot tips could be maintained in culture during 12 months using protocol A but only 7 months using protocol B. Furthermore, proliferation rate drastically diminished: 'Tomuri' explants cultured in medium M4 formed 1.75 new shoots per explant

\section{A) 'T omuri' in M1}

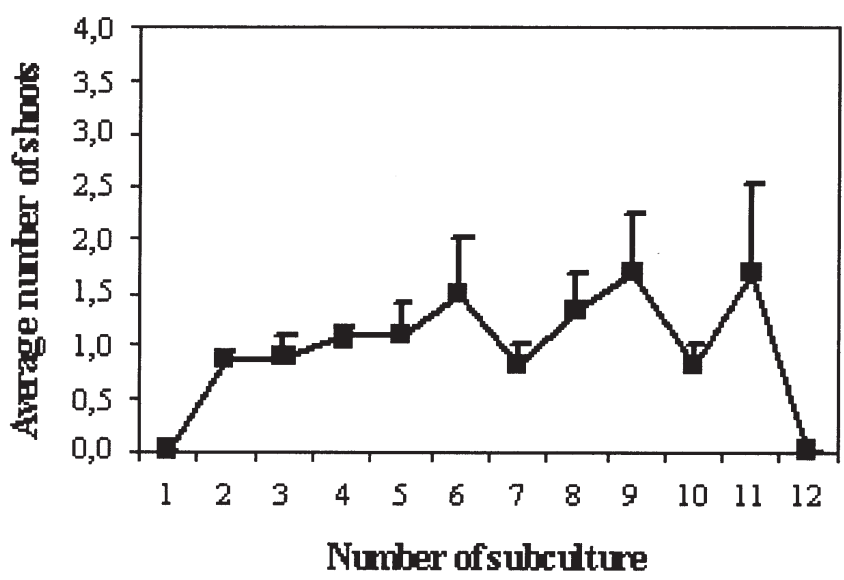

B) 'T omuri' in ML2

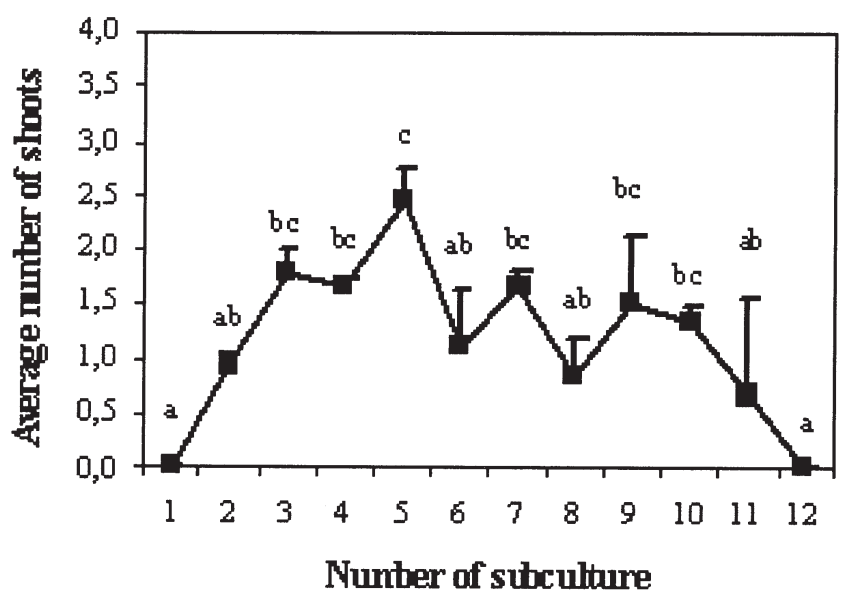

C) 'T omuri' in M4

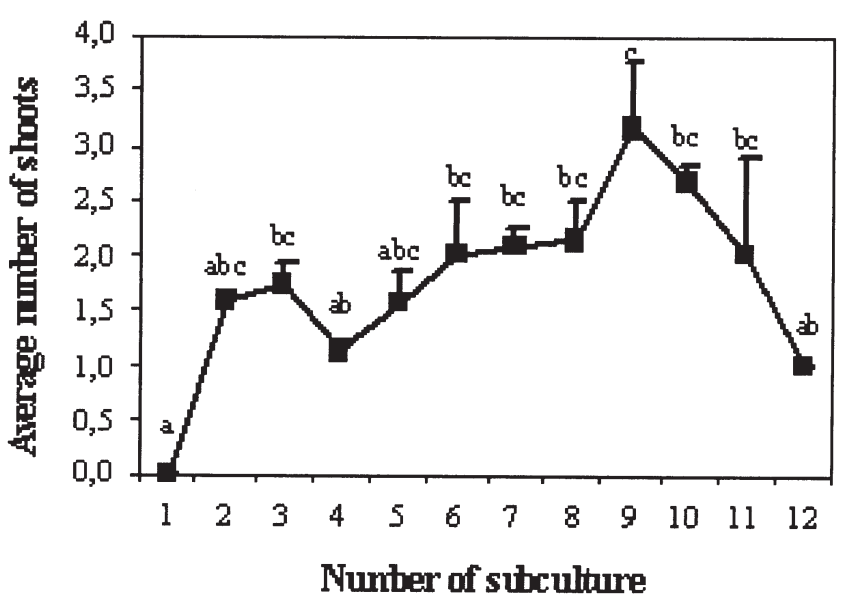

D) Clone A in M1

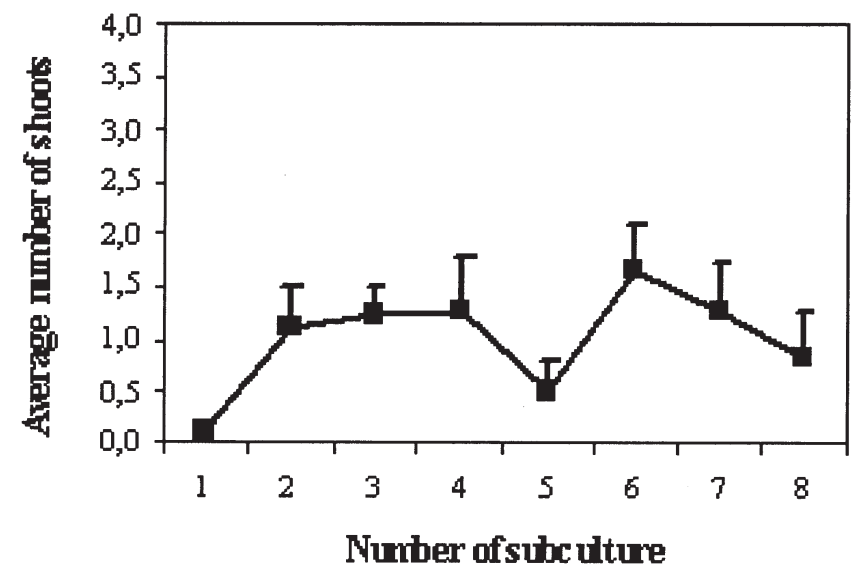

E) Clone $\mathrm{A}$ in $\mathrm{ML}$

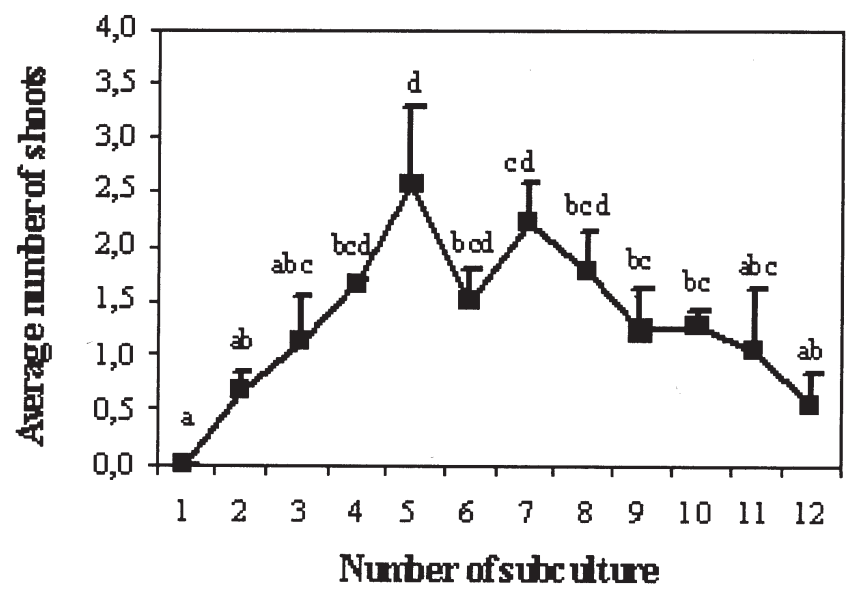

F) Clone A in M4

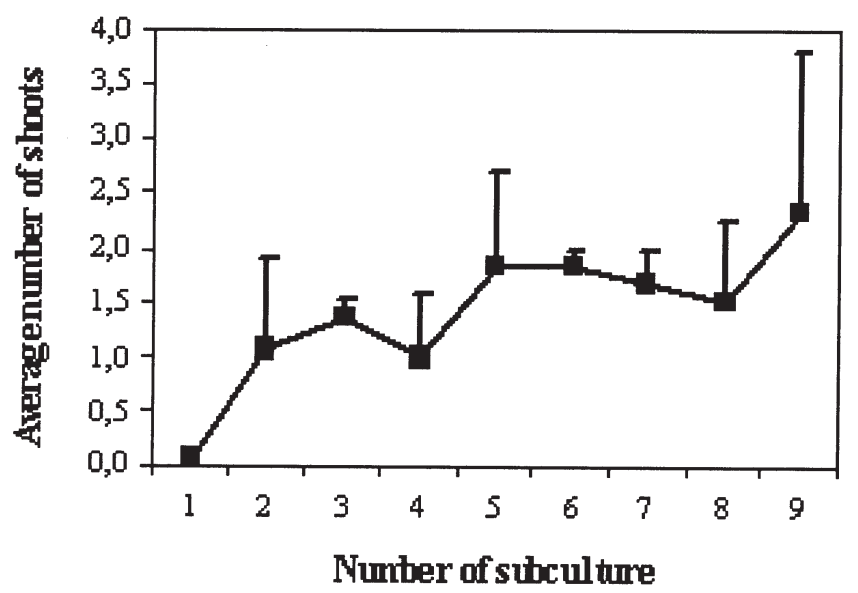

Fig. 1. Effect of growth regulator combination on shoot induction from shoot tips of adult grown plants. 'Tomuri' explants cultured in (A) M1 medium (0.1 $\mu \mathrm{M}$ NAA, $0.4 \mu \mathrm{M}$ BA and $0.3 \mu \mathrm{M}$ GA $)$, (B) M2 medium (0.1 $\mu \mathrm{M}$ NAA, $4.4 \mu \mathrm{M}$ BA and $\left.0.3 \mu \mathrm{M} \mathrm{GA}_{3}\right)$, or (C) M4 medium $(0.5 \mu \mathrm{M}$ NAA, $22 \mu \mathrm{M}$ BA and $1.4 \mu \mathrm{M}$ $\mathrm{GA}_{3}$ ). Clone A explants cultured in (D) M1 medium, (E) M2 medium, or (F) M4 medium. Values with the same or without letters are not significantly different at $P \leq 0.05$ by Duncan's multiple range test. Bars above lines represent standard errors. 


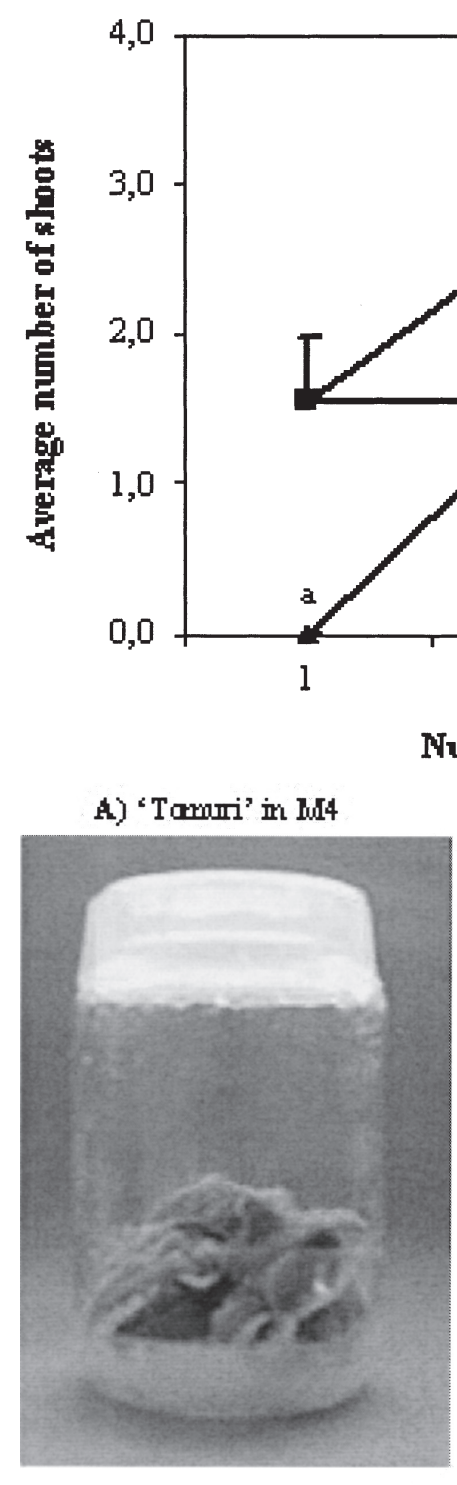

c) 'Tammi' with $\operatorname{TD} Z$

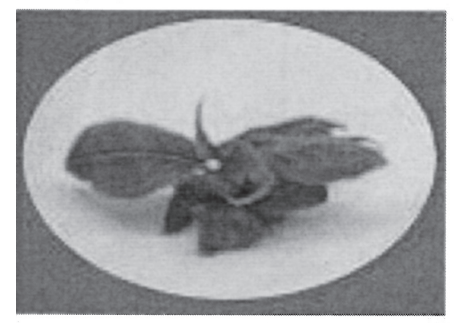

E) Rooted plants

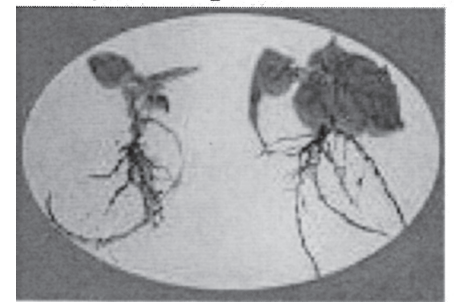

B) Clone A in WD

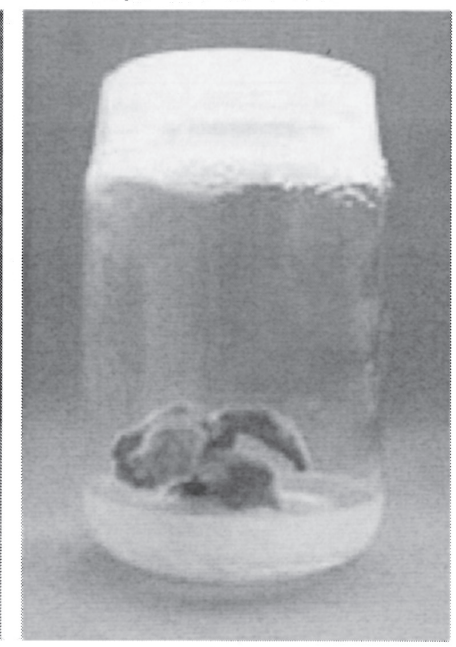

D) 'Tammi' withm T

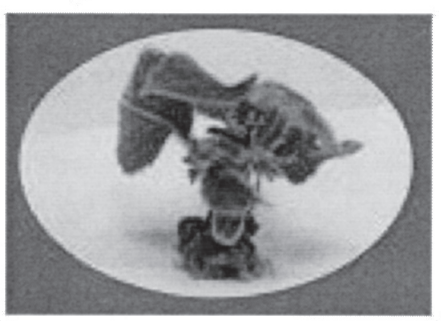

F) Acclinnatixed plarts

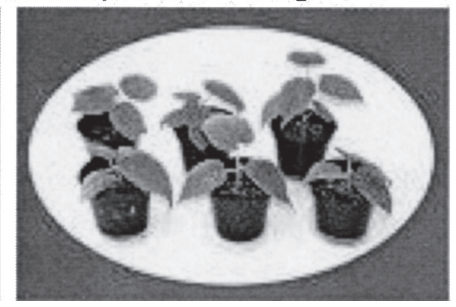

Fig. 2. Effect of a $35 \mathrm{~d}$ pretreatment of TDZ and $\mathrm{mT}$ on shoot induction from shoot tips of 'Tomuri' adult grown plants. Filled squares correspond to explants cultured for $35 \mathrm{~d}$ in the presence of 0.5 $\mu \mathrm{M}$ NAA, $2.2 \mu \mathrm{M}$ TDZ and $1.4 \mu \mathrm{M} \mathrm{GA}_{3}$, and then cultured for four subcultures in M4 medium $(0.5$ $\mu \mathrm{M}$ NAA, $22 \mu \mathrm{M}$ BA and $1.4 \mu \mathrm{M} \mathrm{GA}_{3}$ ). Filled circles correspond to explants cultured for $35 \mathrm{~d}$ in the presence of $0.5 \mu \mathrm{M}$ NAA, $2 \mu \mathrm{M} \mathrm{mT}$ and 1.4 $\mu \mathrm{M} \mathrm{GA}$, and then cultured for four subcultures in M4 medium. Filled triangles correspond to explants cultured directly in M4 medium. For each cytokinin treatment, values with the same or without letters are not significantly different at $P \leq 0.05$ by Duncan's multiple range test. Bars above lines represent standard errors.
G) Clone A plant in field

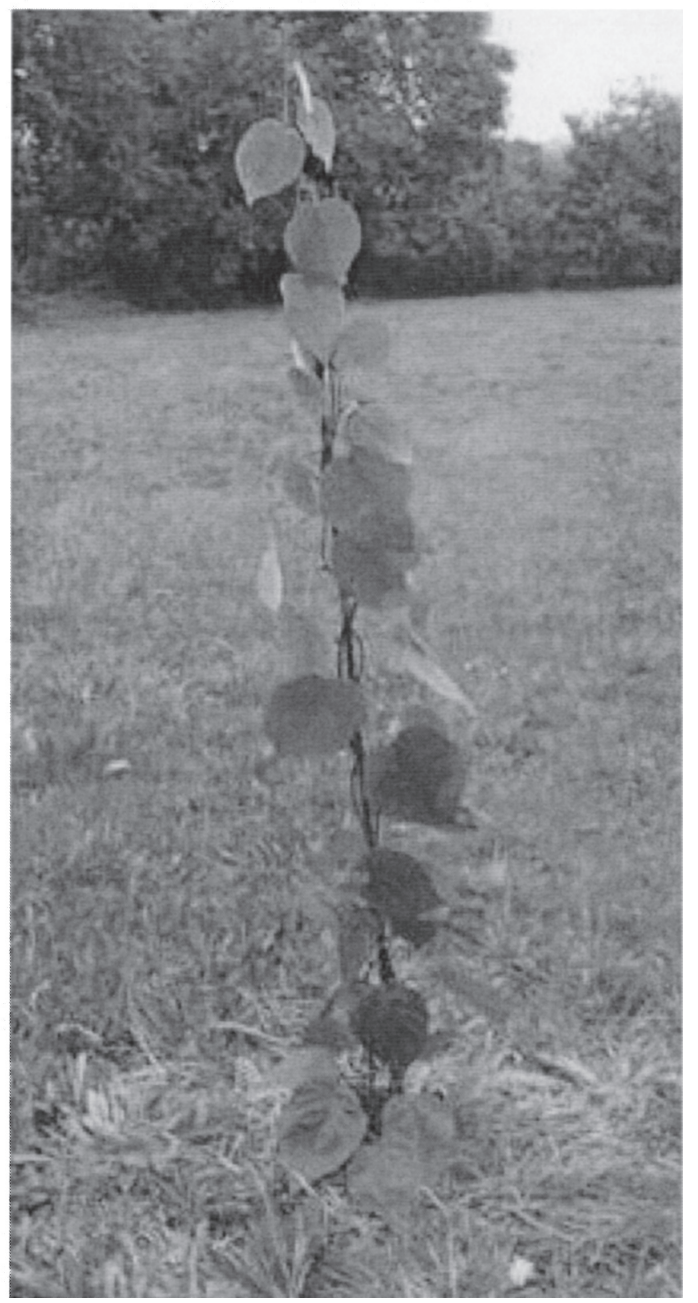

Fig 3. Micropropagation of shoot-tips from field grown 'Tomuri' and clone A cuttings: (A) Shoot formation in 'Tomuri' shoot-tips cultured for six subcultures in M4 medium $\left(0.5 \mu \mathrm{M}\right.$ NAA, $22 \mu \mathrm{M}$ BA and $\left.1.4 \mu \mathrm{M} \mathrm{GA}_{3}\right)$. (B) Shoot formation in clone A shoot-tips cultured for 5 subcultures in M2 medium $(0.1 \mu \mathrm{M}$ NAA, $4.4 \mu \mathrm{M}$ BA and $\left.0.3 \mu \mathrm{M} \mathrm{GA}_{3}\right)$. (C) Shoot formation in 'Tomuri' shoot-tips cultured for one subculture in M4 medium $(0.5 \mu \mathrm{M}$ NAA, $22 \mu \mathrm{M} \mathrm{BA}$ and $1.4 \mu \mathrm{M}$ GA $)$ after being pretreated in the presence of $0.5 \mu \mathrm{M}$ NAA, $2.2 \mu \mathrm{M} \mathrm{TDZ}$ and $1.4 \mu \mathrm{M} \mathrm{GA}$. (D) Shoot formation in 'Tomuri' shoot-tips cultured for 1 subculture in M4 medium ( 0.5 $\mu \mathrm{M} \mathrm{NAA}, 22 \mu \mathrm{M} \mathrm{BA}$ and $1.4 \mu \mathrm{M} \mathrm{GA}_{3}$ ) after being pretreated in the presence of $0.5 \mu \mathrm{M} \mathrm{NAA}, 2 \mu \mathrm{M}$ MT and $1.4 \mu \mathrm{M} \mathrm{GA}_{3}$. (E) Rooted Tomuri (left) and clone A (right) microshoots after basal immersion in an IBA solution $(5 \mathrm{mM})$ for $15 \mathrm{~s}, 1$ month in half-strength $\mathrm{K}(\mathrm{h})$ basal medium and $10 \mathrm{~d}$ in sterile peat-perlite substrate. (F) 'Tomuri' and clone A acclimated plants after 3 months in the greenhouse. (G) Clone A plant actively growing after 1 year in the field. 
TC $\mathrm{CAC} 9 \mathrm{~T}$ 12T $5 \mathrm{CA} \quad 12 \mathrm{CA}$

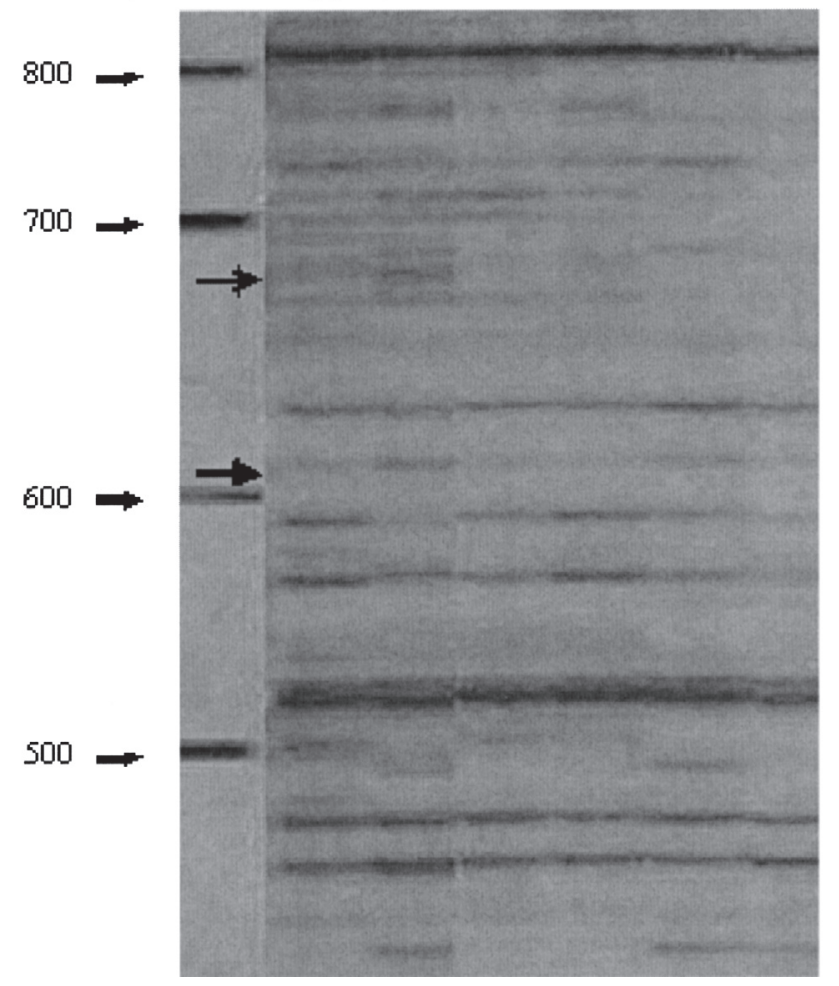
using protocol A, but only 0.89 using protocol B (data not shown).

Therefore, in this study, the in vitro results presented are only those obtained using shoottips from hardwood cuttings, sterilised and stored according protocol A.

Effect of hormonal concentration. When the culture medium was not supplemented by growth regulators, shoot multiplication did not occur since all explants died during the first month in culture. In M3 medium, explants did not survive more than 3 months and no shoots were observed. In the other three media, shoot proliferation could be observed, but new shoots were never found at the first subculture which indicates that the explants needed a short period of time in order to adapt to culture media (George, 1993). From the second subculture, there was a good proliferation rate but it declined as the culture aged. This decline has also been reported by Margara (1988) and is explained by mutations or loss of endogenic hormones or nutrients.

'Tomuri' explants were kept in culture for 12 months in three morphogenic media (Fig. 1). M4 medium yielded the best results, with 3.16 new shoots in the ninth month representing the best subculture (Fig. 1C). Likewise, it was possible to obtain more than two new shoots per explant during six subcultures (between the sixth and the 11th). Explants cultured in medium M1 (Fig. 1A) and M2 (Fig. 1B) formed only 1.66 and 2.44 new shoots per explant in their best subculture, respectively.

Clone A explants could only be cultured for eight subcultures in the M1 medium (Fig. 1D) and nine in the M4 medium (Fig. 1F), whereas in the M2 medium it survived for 12 subcultures (Fig. 1E). The average number of new shoots formed was 1.3 in M2, reaching a
Fig 4. Portion of an AFLP autoradiogram generated with the primercombination number 15 (E-AGC/M-CTT) from $A$. deliciosa DNA. Unnamed lane $100 \mathrm{bp}$ DNAladder(Promega). Lane TC: 'Tomuri' field-grown plants. Lane CAC: Clone A field-grown plants. Lane 9T: 'Tomuri' in vitro shoots taken in the 9th subculture (showing the highest multiplication rate). Lane 12T: 'Tomuri' in vitro shoots taken in the last subculture. Lane 5CA: Clone A in vitro shoots taken in the 5 th subculture (showing the highest multiplication rate). Lane 12CA: Clone A in vitro shoots taken in the last subculture.

maximum of 2.5 in the fifth subculture. Furthermore, this was the only medium in which it was possible to obtain more than 1.5 new shoots per explant during five subcultures (between the fourth and the eighth).

Explants from both pollinizers cultured in media with 1 auxin : 4 cytokinin : 3 gibberellin did not

in the medium. These authors observed shoot hyperhydricity and callus growth at the base of shoots. It has been reported that high BA concentrations can produce hyperhydratated shoots (Ziv, 1991), but we never observed this problem during the present study.

Developed shoots were longer than 0.5 $\mathrm{cm}$ reaching in some subcultures up to $1 \mathrm{~cm}$ in length, for both $\mathrm{GA}_{3}$ concentrations tested $\left(0.3 \mu \mathrm{M} \mathrm{GA}\right.$ or $\left.1.4 \mu \mathrm{M} \mathrm{GA}_{3}\right)$. Although it has been reported that $\mathrm{GA}_{3}$ promotes elongation of internodes and the growth of buds in vitro (Chawla, 2002), the lack of differences among two $\mathrm{GA}_{3}$ concentrations could be explained by the fact that high BA concentrations may decrease $\mathrm{GA}_{3}$ absorption in kiwifruit explants (Moncaleán et al., 2001).

The effect of TDZ and $\mathrm{mT}$ was different in 'Tomuri' and clone A explants. After treatment with TDZ and $\mathrm{mT}$, 'Tomuri' explants survived in several M4 subcultures and showed appreciative shoot multiplication, whereas clone A explants died during the first or second subculture in M2. 'Tomuri' shoot-tips gave a multiplication rate of three new shoots per explant after four subcultures in M4 after prior treatment with TDZ, and after three subcultures when they had been previously treated with $\mathrm{mT}$ (Fig. 2). When explants were directly subcultured in M4 medium they needed nine subcultures to reach such multiplication rates (Fig. 1C).

An increase in the multiplication rate usproduce new shoots per explant (M3 medium) or only allowed to obtain the lowest number of them (M1 medium), whereas increasing BA concentration (M4 and M2 media) to reach a ratio of 1:44:3 stimulated new shoot formation. However, growth regulator concentration requirements were different for both pollinizers. Thus, to reach the best multiplication rate in 'Tomuri', the combination used was $0.5 \mu \mathrm{M}$ NAA, $22 \mu \mathrm{M}$ BA and $1.4 \mu \mathrm{M} \mathrm{GA}_{3}(\mathrm{M} 4)$, while for clone $\mathrm{A}$ it was $0.1 \mu \mathrm{M}$ NAA, $4.4 \mu \mathrm{M} \mathrm{BA}$ and $0.3 \mu \mathrm{M} \mathrm{GA}_{3}(\mathrm{M} 2)$. These multiplication rates are comparable with those reported by Marino and Bertazza (1990) and Piagnani et al. (1986) for 'Tomuri' testing different BA concentrations as the only growth regulator

ing TDZ has been also reported by Ranjan et al. (1997) in Cymbidim aliofolim and Torres and Mogollón (2000) in Cattleya mossiae. However, TDZ does not present this positive effect in all species. For example, in the case of Ocimum sanctum, it has been reported that use of BA induced direct multiple shoots whereas TDZ only led to nonmorphogenetic callus (Nirmal and Sehgal, 1999). On the other hand, results obtained using $\mathrm{mT}$ are consistent with those reported by Fernández (2001) on the female kiwifruit cultivar 'Hayward'. This author has reported that $35 \mathrm{~d}$ is the best incubation period with $\mathrm{mT}$, with an optimum concentration of $2.2 \mu \mathrm{M}$.

Table 2. Analysis of informativeness of primer combinations that gave polymorphisms amongst the samples of in vivo and in vitro grown kiwifruit male genotypes ('Tomuri' and clone A).

\begin{tabular}{lccc}
\hline $\begin{array}{l}\text { Primers } \\
\text { combinations }\end{array}$ & $\begin{array}{c}\text { No. of } \\
\text { total bands }\end{array}$ & $\begin{array}{c}\text { No. of } \\
\text { polymorphics bands }\end{array}$ & $\begin{array}{c}\text { Percentage of } \\
\text { polymorphism }\end{array}$ \\
\hline 1-EcoRI-AAC / MseI-CAA & 96 & 51 & 53 \\
2-EcoRI-AAC / MseI-CAC & 101 & 61 & 60 \\
3-EcoRI-AAC / MseI-CAT & 135 & 71 & 53 \\
4-EcoRI-AAG / MseI-CTG & 62 & 36 & 58 \\
5-EcoRI-AAG / MseI-CTT & 127 & 47 & 37 \\
6-EcoRI-ACA / MseI-CTA & 76 & 31 & 41 \\
7-EcoRI-ACA / MseI-CTC & 90 & 76 & 84 \\
8-EcoRI-ACA / MseI-CTG & 66 & 41 & 62 \\
9-EcoRI-ACA / MseI-CTT & 116 & 43 & 37 \\
10-EcoRI-ACC / MseI-CTA & 105 & 71 & 68 \\
11-EcoRI-ACC / MseI-CTC & 85 & 60 & 71 \\
12-EcoRI-ACT / MseI-CAG & 87 & 43 & 49 \\
13-EcoRI-ACT / MseI-CAT & 76 & 39 & 51 \\
14-EcoRI-AGC / MseI-CTG & 58 & 37 & 64 \\
15-EcoRI-AGC / MseI-CTT & 78 & 70 & 90 \\
Total & 1358 & 777 & 57 \\
Minimum number of polymorphism & & & 36 \\
Maximum number of polymorphism & & & 71 \\
Average number of amplified bands for combination & & & 90.5 \\
Average number of polymorphism for combination & & & 51.8 \\
\hline
\end{tabular}



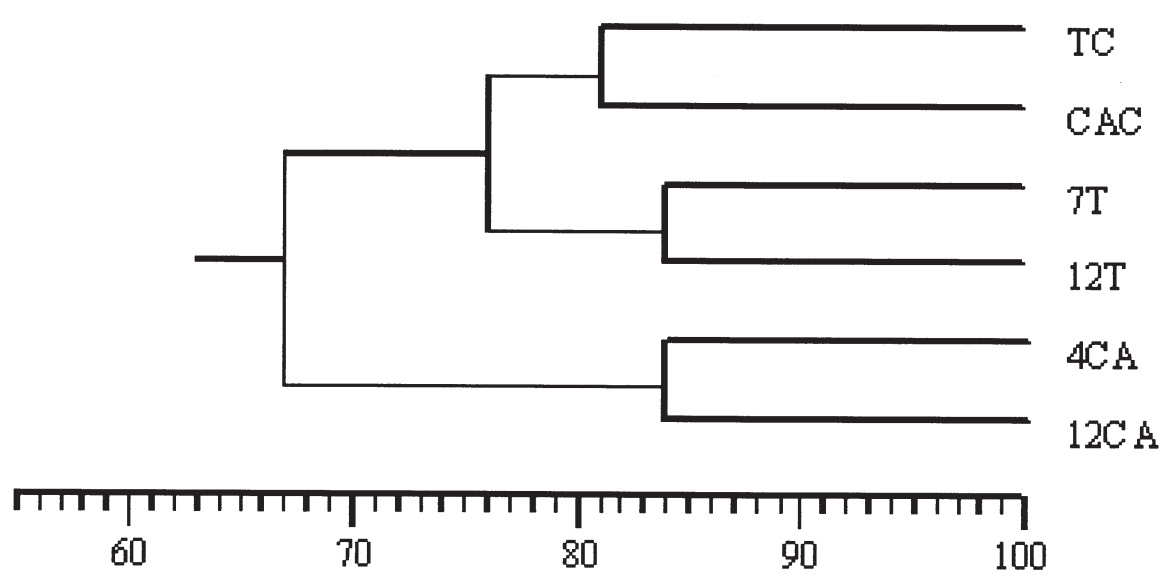

Fig. 5. Dendrogram of 6 kiwifruit genotypes based on the Dice similarity index by 15 primer combination of AFLP markers.

Shoots formed in explants treated with TDZ or $\mathrm{mT}$ were shorter, between 0.3 or $0.4 \mathrm{~cm}$, than those obtained in explants directly cultured in $\mathrm{BA}(>0.5 \mathrm{~cm})$, and they needed to be elongated prior to rooting. Earlier research has reported a reduction in shoot elongation with TDZ (Fellman et al., 1987; Torres and Mogollón, 2000) and mT (Fernández, 2001).

Figure 3 shows 'Tomuri'(A) and clone A(B) shoot multiplication from shoot-tips cultured in M4 medium and M2 medium respectively. This figure also illustrates shoot multiplication from 'Tomuri' shoot-tips treated with a subculture with TDZ (C) or mT (D) after being maintained in M4 medium.

Rooting and acclimatization. All tested shoots rooted after $30 \mathrm{~d}$ in half-strength $\mathrm{K}(\mathrm{h})$ basal medium (Fig. 3E). Plant survival in the greenhouse was high (about $90 \%$, Fig. 3F) and acclimatized plantlets were transferred to field conditions where they remain still, after 1 year actively growing (Fig. 3G). Results are similar to those reported by González et al. (1995) with 'Hayward'.

Genetic variation analysis. Analysis by AFLP using 15 primer combinations showed reproducible and well-resolved bands (Fig. 4). A total of 1358 fragments were obtained, 777 of which were polymorphic (57\%), where the combination number seven gave 76 polymorphic bands and only 31 with the primer combination number six. However, no clear correlation was observed between total number of bands and percentage of polymorphism (Table 2), since the greatest percentage was for the combination number 15 , and the lowest for nine.

A dendrogram was constructed from a matrix that included both monomorphic and polymorphic bands to express the results of the cluster analyses based on the AFLP fragments (Fig. 5). The correlation coefficient calculated for AFLP markers was $r=0.923$. This value indicated that the matrix obtained was a good representation of the relationships among the genotypes, as reported by Rohlf (1993), who considered a value of $r=0.82$ to be significant. When the results expressed by the dendrogram were considered with respect to the tissue culture effects it could be seen that AFLP markers reflected genetic variation through the culture process.

Genetic variation in kiwifruit during tissue culture has been analysed previously by Palombi and Damiano (2002) using two different DNA-based techniques, RAPD and SSR. These authors observed that RAPD markers could not detect genetic variation induced in micropropagated 'Tomuri' plants, whereas SSR showed genetic variation induced during in vitro culture. Our results showed that AFLP markers also discriminate genetic variation, which makes them more effective than RAPD markers, as previously described in studies comparing different DNA-based techniques (Powell et al., 1996; Russell et al., 1997). Thus, SSR used by Palombi and Damiano (2002) and AFLP used in the present work are valid DNA-based techniques for analyzing genetic variation in kiwifruit induced by in vitro culture.

The dendrogram showed that there was a greater similarity between 'Tomuri' and clone Afield-grown plants, as previously observed in studies to identify clones of $A$. deliciosa with isozymes, RAPD and AFLP markers (Prado, 2002), than there was between in vitro material and their corresponding mother plant (Fig. 5). There was also a good correlation of similarity between in vitro material and its corresponding field-grown material of the same genotype.

More genetic variation was observed in clone A ( $67 \%$ similarity between in vitro and in vivo plants) than 'Tomuri' ( $76 \%$ similarity). In fact, several studies have revealed that different genomes do not respond in the same way to in vitro culture stress. These differences are shown even among varieties of the same species, depending on the different ploidy level of the starting material (Karp, 1991). Another factor that induces genetic variation seems to be the time of culture. However, we have detected that variation does not seem to be influenced by the number of subcultures (Fig. 5). These results are consistent with studies which indicate that most changes occur during the first stages of culture, when cells are under greater stress (Yamagishi, 1996).

We have designed a simple protocol for the micropropagation of two adult field-grown plant pollinizers of kiwifruit. This protocol includes the most effective system for storing cuttings in order to avoid bacterial and fungal proliferation at the time when the culture is established. Three different cytokinins have been evaluated for shoot multiplication, being TDZ and $\mathrm{mT}$ more effective than BA. BA proved to be useful for obtaining shoots amenable to rooting and transfer to field, whereas this was not tested with the shorter shoots obtained using TDZ and $\mathrm{mT}$. Since multiplication and elongation can be carried out in the same step using BA, this protocol also reduces costs in developing plants. Further this study report that AFLP markers are able to investigate genetic variation in micropropagated plants. It is possible conclude that when we use molecular markers with this aim, the choice of DNA analysis technique is relevant and depends on both the efficiency with which the molecular markers detect polymorphism and the different level of DNA changes occurring in the plants.

\section{Literature Cited}

Barnett, H.L. and B.B. Hunter. 1987. Illustrated genera of imperfect fungi. 4th ed. Macmillan, New York.

Cassells, A.C. and R.F. Curry. 2001. Oxidative stress and physiological, epigenetic and genetic variability in plant tissue culture: implications for micropropagators and genetic engineers. Plant Cell Tissue Organ Cult. 64:145-157.

Chawla, H.S. 2002. Introduction to plant biotechnology. 2nd ed. Science Publ. Inc., Enfield, N.H.

Cheng, T.Y. 1975. Adventitious bud formation in culture of douglas fir (Pseudotsuga menziesii (Mirb.) Franco). Plant Sci. Lett. 5:97-102.

Cipriani, G. and M. Morgante. 1993. Evidence of choroplast DNA variation in the genus Actinidia revealed by restriction analysis of PCR-amplified fragments. J. Genet. Breed. 47:319-326.

Cook, R.J. and K.F. Baker. 1983. The nature and practice of biological control of plant pathogens. APS Press. St. Paul, Minn.

Di Marco, S., G. Spada, and F. Osti. 2002. La carie dell'actinidia. Frutticoltura 9:59-63.

Doyle, J.J. and Doyle, J.L. 1990. Isolation of plant DNA from fresh tissue. Focus 12:13-15.

Ellis, M.B. 1971. Dematiaceous Hyphomycetes. C.M.I., Kew, England.

Fellman, C., P. Read, and M. Hosier. 1987. Effects of thidiazuron and CPPU on meristem formation and shoot proliferation. HortScience 22:1197-1200.

Fernández, D. 2001. Utilización de meta-Topolina en la optimización de la micropropagación de Actinidia deliciosa. MS thesis. Univ. of Oviedo, Spain

George, E.F. 1993. Plant propagation by tissue culture. part 1. The technology. 2nd ed. Exegetics Ltd, Edington, Wilts, England.

Gerlach, M., J.J. Amsing, W.M.L. Molhoek, A.I. Bosker Van Zessen, C.H. Lombaers Van DerPlas, and J. Köhl. 2001. The effect of treatment with Ulocladium atrum on Botrytis cinerea-attack of geranium (Pelargonium zonale) stock plants and cuttings. Eur. J. Plant Pathol. 107:377-386.

Gianetti, G., A. Cotroneo, M.C. Garofalo, A. Galliano, and F. Vittone. 2002. Acquisizione pre liminari sul deperimento lignicolo dell'actinidia in Piemonte. Frutticoltura 9:65-68.

González, M.V., M. Coque, and M. Herrero. 1994. Pollinator selection in kiwifruit (Actinidia deliciosa). J. Hort. Sci. 70:375-378. 
González, M.V., M. Coque, and M. Herrero. 1998. Influence of pollination systems on fruit set and fruit quality in kiwifruit (Actinidia deliciosa). Ann. Appl. Biol. 1320:349-355.

González, M.V., M. Rey, and R. Rodríguez. 1995. Plant regeneration from petioles of kiwifruit microshoots. HortScience 30:1302-1303.

Hashmi, G., R. Huettel, R. Meyer, L. Krusber, and F. Hammerschlag. 1997. RAPD analysis of somaclonal variants derived from embryo callus cultures of peach. Plant Cell Rep. 16:624-627.

Karp, A. 1991. On current understaning of somaclonal variation, p. 1-58. In: B.L. Miflin (ed.). Surveys of Plant Molecular and Cell Biology, Vol. 7, Oxford, Clarendon Press and Oxford University Press, London and Oxford.

Köhl, J., M. Gerlach, B.H. De Haas, and M.C. Krijger. 1998. Biological control of Botrytis cinerea in Cyclamen with Ulocladium atrum and Gliocladium roseum under commercial growing conditions. Phytopathology 88:568-575.

Larkin, P.J. and W.R. Scowcroft. 1981. Somaclonal variation-A novel source of variability from cell cultures for plant improvement. Theor. Appl. Genet 60:197-214.

Manning, K. 1991. Isolation of nucleic acids from plant by differential solvent precipitation. Anal. Biochem. 195:45-50.

Mantel, N.A. 1967. The detection of disease clustering and a generalized regression approach. Cancer Res. 27:209-220.

Margara, J. 1988. Multiplicación vegetativa y cultivo in vitro. Mundi-Prensa, Madrid, Spain.

Marino, G. and G. Bertazza. 1990. Micropropagation of Actinidia deliciosa cvs. 'Hayward' and 'Tomuri'. Scientia Hort. 45:65-74.

Moncaleán, P., A. Rodríguez, and B. Fernández. 2001. In vitro response of Actinidia deliciosa explants to different BAincubation periods. Plant Cell Tissue Organ Cult. 67:257-266.

Monette, P.L. 1986. Micropropagation of kiwifruit using nonaxenic shoot tips. Plant Cell Tissue Organ Cult. 6:73-82.

Nirmal, K. and C.B. Sehgal. 1999. Micropropagation of "holy basil" (Ocimum sanctum Linn.) from young inflorescences of mature plants. Plant Growth Regulat. 29:161-166.

Palombi, M.A. and C. Damiano. 2002. Comparison between RAPD and SSR molecular markers in detecting genetic variation in kiwifruit (Actinidia deliciosa A. Chev). Plant Cell Rep. 20:1061-1066.

Pedroso, M.C., M.M. Oliveira, and M.S.S. Pais. 1992. Micropropagation and simultaneous rooting of Actinidia deliciosa var. deliciosa cv. 'Hayward' . HortScience 27:443-445.

Piagnani, C., T. Eccher, and S. Castelli. 1986. Micropropagation of Actinidia chinensis: effects of growth regulators on proliferation rate. Acta Hort. 179: 887-890.

Powell, W., A. Morgante, C. Andre, M. Hanafey, J. Vogel, S. Tingey, and A. Rafalski. 1996. The comparison of RFLP, RAPD, AFLP and SSR (microsatellite) markers for germplasm analysis. Mol. Breed. 2:225-238.

Prado, M.J. 2002. Micropropagation, organogenesis and biochemical and molecular identification male plants of kiwifruit (Actinidia deliciosa (Chev.) Liang and Ferguson var. deliciosa). $\mathrm{PhD}$ thesis. Univ. Santiago de Compostela, Spain.

Ranjan, N., S. Prasad, and S. Patnaik. 1997. In vitro propagation of three epiphytic orchids, Cymbidium aloifolium, Dendrobium aphylum and D. moschatum, through thidiazuron induced high frequency shoot proliferation. Scientia Hort. 71:243-250.

Revilla, M.A., M. Rey, F. González-Rio, M.V. González, C. Díaz-Sala, and R. Rodríguez. 1992. Micropropagation of kiwi (Actinidia spp.), p. 339-423. In: Y.P.S. Bajaj (ed.). Biotechnology in agriculture and forestry, high tech and micropropagation II.. Springer-Verlag, Berlin.

Rohlf, F.J. 1993. NTSYSPC. Numerical taxonomy system. Exeter Software, New York.

Russell, J.R., J.D. Fuller, M. Macaulay, B.G. Hartz, A. Jahoor, W. Powell, and R. Waugh. 1997. Direct comparison of levels of genetic variation among barley accessions detected by RFLPs, AFLPs, SSRs and RAPDs. Theor. Appl. Genet. 95:714-722.

Sabir, A., H.J. Newbury, G. Todd, J. Catty, and B.V. Ford-Loyd. 1992. Determination of genetic stability using isozymes and RFLPs in beet plants regenerated in vitro. Theor. Appl. Genet. 84:113-117.

Schneider, S., G. Reustle, and E. Zyprian. 1996. De- tection of somaclonal variation in gravepine from protoplast by RAPD-PCR. Vitis 35:99-100.

Sutton, B.C. 1980. The Coelomycetes. C.M.I., Kew, England.

Testolin, R., W.G. Huang, O. Lain, R. Messina, A. Vecchione, and G. Cipriani. 2001. A kiwifruit (Actinidia spp.) linkage map based on microsatellites and integrated with AFLP markers. Theor. Appl. Genet. 103:30-36.

Thanassoulopoulos, C.C. and L. Yanna. 1997. On the biological control of Botrytis cinerea on kiwifruit cv 'Hayward' during storage. Acta Hort. 444:757-764.

Torres, J. and N. Mogollón. 2000. Micropropagación de Cattleya mossiae Parker ex hook brotación axilar inducida por tidiazuron. Bioagro 12:10-14.

Velayandom, L., A.M. Hirsch., and D. Fortune. 1985. Tissue culture of nodal stem segments of Actinidia chinensis (L.) Planchon, as a method of micropropagation. C.R. Acad. Sci. Ser. III 301:597-600.

Vendrame, W.A., G. Kochert, and H.Y. Wetzstein. 1999. AFLP analysis of variation in pecan somatic embryos. Plant Cell Rpt. 18:853-857.

Vos, P., R. Hogers, M. Bleeker, M. Reijans, T. Van de Lee, M. Hornes, A. Frijters, J. Pot, J. Peleman, M. Kuiper, and M. Zabeau. 1995. AFLP: a new technique for DNA fingerprinting. Nucleic Acids Res. 23:4407-4414.

Wessels, E., D.D. Nel, and D.F.A.Von Staden. 1984. In vitro propagation of Actinidia chinensis $\mathrm{Pl}$. cultivar 'Hayward'. Deciduous Fruit Grower 34:453-457

Yamagishi, M., M. Otani, and T. Shimada. 1996. A comparison of somaclonal variation in rice plants derived and not derived from protoplasts. Plant Breed. 115:289-294.

Zhang, J. and T.G. Thorp. 1986. Morphology of nine pistillate and three staminate New Zealand clones of kiwifruit (Actinidia deliciosa (Chev.) Liang and Ferguson var. deliciosa). N.Z. J. Bot. 24:589-613.

Ziv, M. 1991. Vitrification morphological and physiological disorder of in vitro plants, p. 45-49. In: R.C. Debergh and R.H. Zimmerman (eds.) Micropropagation. Technology and application. Kluwer Academic Publ., Dordrecht. 